\title{
Accuracy of self-perforating impression tray for maxillary dental implant
}

\author{
- Lauren Bohner Department of Prosthodontics, School of Dentistry, University of São Paulo, São Paulo, \\ SP, Brazil A André Duarte Azevedo Marques Department of Prosthodontics, School of Dentistry, University of \\ São Paulo, São Paulo, SP, Brazil - Caroline Bosquê Keedi Department of Prosthodontics, School \\ of Dentistry, University of São Paulo, São Paulo, SP, Brazil • Washington Steagall Discipline of Restorative Dentistry, Nove de \\ Julho University, São Paulo, SP, Brazil - Pedro Tortamano Neto Department of Prosthodontics, School of Dentistry, \\ University of São Paulo, São Paulo, SP, Brazil
}

ABSTRACT || Objectives: To analyze the accuracy of a pre-fabricated self-perforating tray for implant impression in an edentulous maxilla. Methods: Four implants $(13,16,23,26)$ were placed in an acrylic resin model of an edentulous maxilla. Implant impressions ( $\mathrm{n}=7$ ) were taken using a customized open tray (Control Group) and a pre-fabricated selfperforating tray (Test Group). A metal bar was fabricated and screw-retained on implant 13 and the vestibular gap between the framework and implants was measured by stereomicroscopy on implants 16, 23, and 26. Data were analyzed by ANOVA repeated measures and Tukey tests with a significance level $(\alpha)$ of 0.05 . Results: There was no statistical difference between self-perforating and customized open tray groups. Control group showed a gap of $73.31 \pm 26.01$ for I1; $149.16 \pm 53.90$ for I2; and $115.46 \pm 73.34$ for I3. Whereas Test Group showed a gap of $154.41 \pm 74.64$ for I1; $159.45 \pm 87.64$ for I2; and $109.28 \pm 49.18$ for I3. Conclusion: The pre-fabricated self-perforating and custom trays showed a similar accuracy for implant impression of edentulous maxilla.

DESCRIPTORS || Impression Technique; Dental Implants; Dimensional Measurement Accuracy.

RESUMO | Precisão de moldeira autoperfurante para impressão de implante dentário maxilar • Objetivos: Analisar a precisão de uma moldeira autoperfurante de impressão pré-fabricada para implantes na maxila edêntula. Métodos: Quatro implantes $(13,16,23,26)$ foram colocados em um modelo de resina acrílica de uma maxila edêntula. As impressões dos implantes $(n=7)$ foram tiradas com uma moldeira aberta customizada (Grupo Controle) e uma moldeira autoperfurante pré-fabricada (Grupo Teste). Uma barra de metal foi fabricada e aparafusada no implante 13, e o gap vestibular entre a estrutura e os implantes foi medido por estereomicroscopia nos implantes 16, 23 e 26. Os dados foram analisados por Anova de medidas repetidas e teste de Tukey, com um nível de significância ( $(\alpha)$ de 0,05. Resultados: Não houve diferença estatística entre os grupos de moldeiras, tanto autoperfurante quanto aberta customizada. O grupo controle apresentou gaps de 73,31 $\pm 26,01$ para I1; $149,16 \pm 53,90$ no I2; e 115,46 \pm 73,34 para o I3. Ao passo que o Grupo Teste apresentou gaps de 154,41 \pm 74,64 no I1; 159,45 \pm 87,64 no I2; e 109,28 \pm 49,18 para o I3. Conclusão: A moldeira autoperfurante pré-fabricada e a moldeira customizada apresentaram precisão similar na impressão de implantes da maxila edêntula.

DESCRITORES | Técnica de Impressão; Implantes Dentários; Precisão da Medição Dimensional.

CORRESPONDING AUTHOR | - Lauren Oliveira Lima Bohner Department of Prosthodontics, School of Dentistry, University of São Paulo • Av. Prof. Lineu Prestes, 2227 São Paulo, SP, Brazil • 05508-000 E-mail: lauren@usp.br

- Received Aug 11, 2017 • Accepted Dec 20, 2017

- Dol http://dx.doi.org/10.11606/issn.2357-8041.clrd.2018.135626 


\section{INTRODUCTION}

Passive fit of an implant-supported dental prosthesis is determinant to provide the long-term success of oral rehabilitation, since a misfit may lead to mechanical complications such as screw loosening, screw fracture or the induction of an internal load on the prosthesis, implants, and bone. Furthermore, biological events have been reported due to the increase in plaque accumulation, resulting in implant failure. ${ }^{1-5}$

The accuracy of an implant impression is one of the most important factors to determine the fit of restorations, provided that the implant position in the patient's mouth is entirely reproduced in the cast model. ${ }^{6,78}$ Therefore, obtaining an adequate implant impression is an important step to avoid misfit of the implant-supported prosthesis. . $^{1,3,5,6,9,10}$ Currently, the pick-up technique offers the most accurate implant positioning reproduction when the impression is taken of 3 or more implants. ${ }^{11,12}$ The main disadvantage of the pick-up technique is the large tray holes and long guide screws, which make them difficult to use in mouths with opening restrictions and in the posterior areas. ${ }^{13,14}$

However, a tray design was developed to make it faster and easier to take impressions of dental implants. The self-perforating tray holds a thin plastic film on the occlusal surface, allowing it to be perforated by the transfers during tray positioning. This feature leads to a clean and precise impression, without excess material on abutments. ${ }^{15}$ Despite all its advantages, the accuracy of impressions obtained with the self-perforating tray is still controversial. ${ }^{15}$ Furthermore, there are no reports evaluating the use of this new technology for maxillary impressions.

Several studies reported the influence of impression technique and implant position on the accuracy of dental casts. ${ }^{16-23}$ With this regard, gap measurements are commonly used to evaluate the fit of implants; hence, most studies use the gap width to evaluate the marginal discrepancy. ${ }^{1,924,25}$ Thus, the aim of this study was to evaluate the accuracy of the self-perforating tray for taking an implant impression of the edentulous maxilla when compared with the conventional pick-up technique. The null hypothesis was that there would be no difference in accuracy between the two types of trays for maxillary implant impressions.

\section{MATERIAL AND METHODS}

\section{Sample preparation}

An acrylic resin master model representing an edentulous maxilla was used in this study. Perforations were made in the region of the canine and first molar $(13,16,23,26)$, in which 4 implants (Straumann, Basel, Switzerland) were fixed with utility wax (Epoxiglass, Diadema, Brazil), as shown in Figure 1. The implant on tooth 13 was kept as reference (IR) for screw tightening and the remaining implants were evaluated (Tooth $16=$ I1, $23=\mathrm{I} 2$, and $26=\mathrm{I} 3$ ).

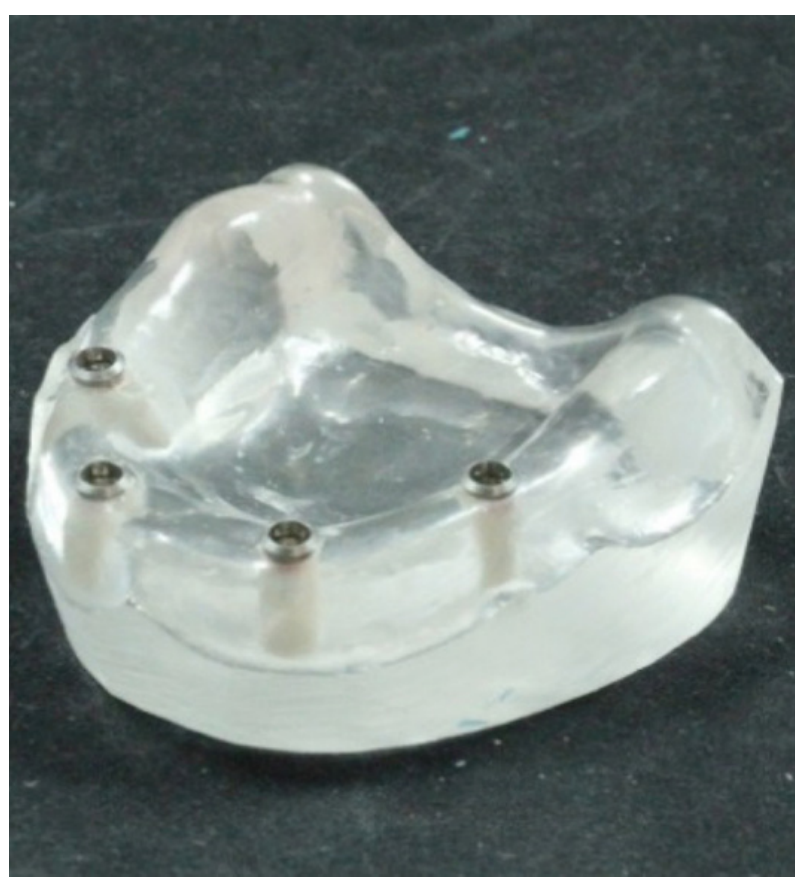

Figure 1 | Master model. 
A cobalt-chromium bar was fabricated using a wax pattern (S-U-Flexible Wax; Schuler-Dental) and cast in cobalt chromium alloy (Remanium 2000; Dentaurum J.P. Winkelstroeter KG). Posteriorly, the bar was screw-retained onto the implants. Toensure an optimal fit, the implants were firstly removed from the model to be individually fixed to the bar. After that, the whole set was fixed to the model using acrylic resin. Subsequently, the entire set was repositioned in the perforations and the implants were fixed to the master model with acrylic resin..$^{15}$

\section{Impression procedures}

Two types of impression trays were evaluated (n = 7): Customized open impression trays (G1 - Control group) and pre-fabricated selfperforating impression trays (G2 - Test group). For the conventional open tray group, individual trays with perforations at the site of the impression copings were fabricated with acrylic resin (Jet, Clássico, São Paulo, Brazil). One tray was used to each impression. Likewise, for the self-perforating group, as the film was perforated after use, a new tray was obtained (Miratray Implant, Hager and Werken $\mathrm{GmbH}$ ) to each impression (Figure 2).

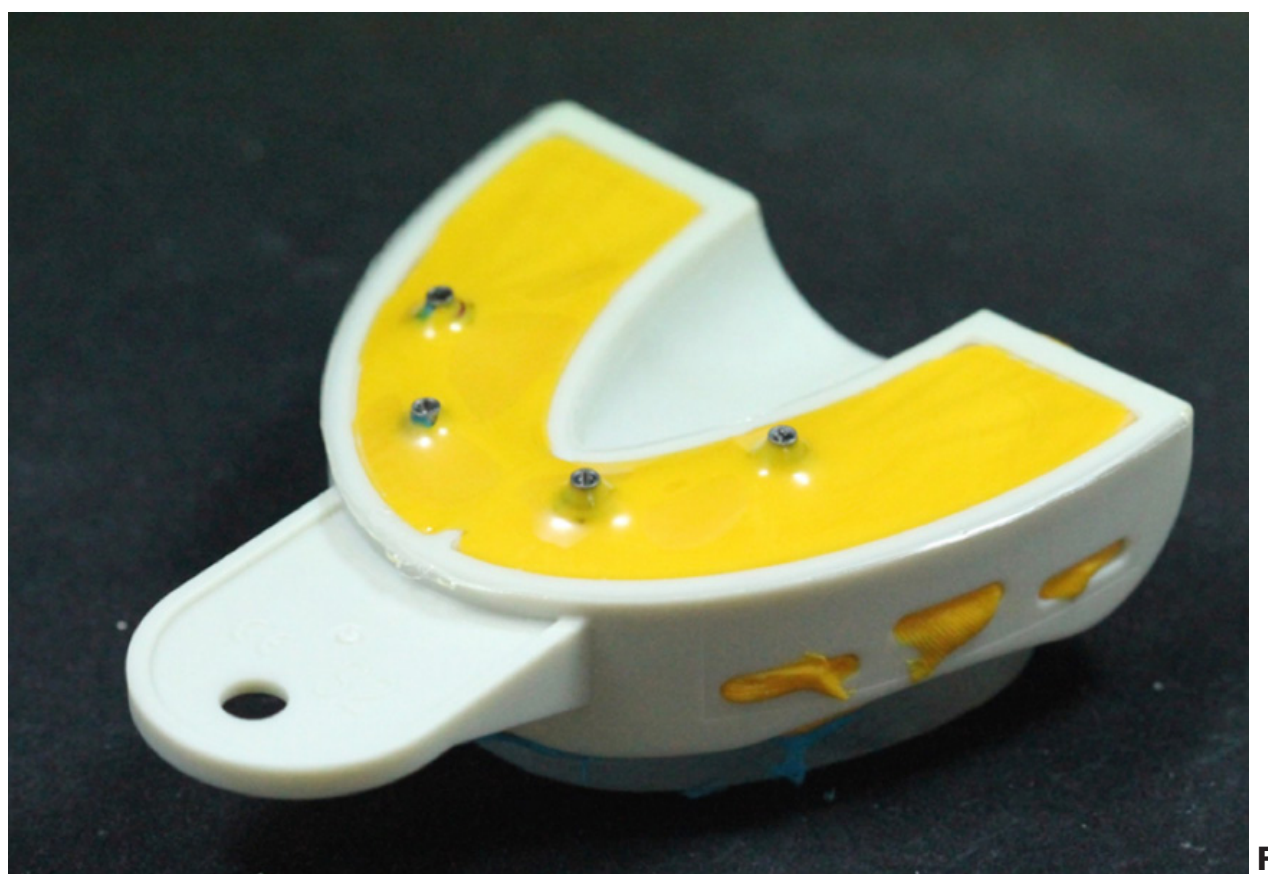

Figure 2 | Self-perforating tray.

Firstly, the impression copings (Square transfer, 4.5, Conexão, São Paulo, Brazil) were positioned on the implants and an adhesive (Universal Tray Adhesive, Zhermack, Rome, Italy) was applied to the trays. For both groups, impressions were taken with polyvinyl siloxane (Express, 3M ESPE, St. Paul, USA), manipulated according to the manufacturer's instructions. After impressiontaking, implant analogs were positioned on the transfer components and dental stone (Type IV, Durone, Dentsply, Petrópolis, Brazil) was poured, after being mixed in accordance with the manufacturer's instructions. Dental casts were stored at $37^{\circ} \mathrm{C}$ for 2 weeks.

\section{Accuracy analysis}

For both groups, the metal bar was adapted to each cast model, to analyze the fit accuracy 
between the bar and the implants. The bar was tightened on implant IR with a torque of $30 \mathrm{Ncm}$, and the vertical distance between the implant and the bar was measured in implants I1, I2, and I3. The gap was evaluated with a stereomicroscope (40x magnification, Zeiss SV11, Carl Zeiss, Jena, Germany).

Measurements were taken in the entire gap and the mean value was calculated and determined as the value of the gap (Figure 3). For each implant, measurements were performed 3 times by the same examiner at intervals of one week. The final gap was defined as the average value of these measurements. The effects of "Tray type" and "Position of implants" were assessed by ANOVA repeated measures and Tukey tests. The T-test was used to evaluate the effect of "Tray type" for each implant. Statistical analysis was performed with the software SPSS 20 (IBM Corp., Chicago, USA) at a level of significance $\mathrm{p}=0.05$.

Figure 3 | Measurement area to determine the mean gap value.

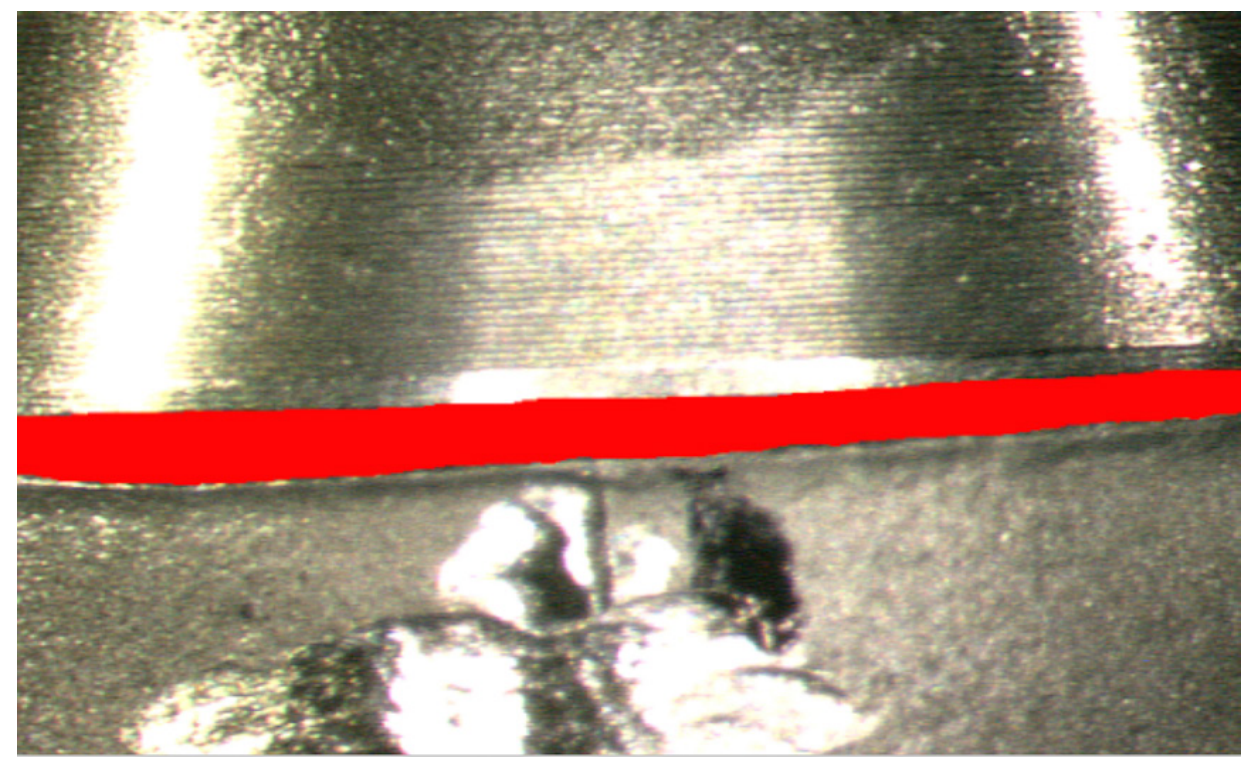

\section{RESULTS}

All data presented variance normality and homogeneity, and were described as mean value \pm standard deviation (Table 1 , Figure 4). The tray type presented no statistically significant difference ( $\mathrm{p}=0.192)$, and no relationship was found between the tray and the implant position $(\mathrm{p}=0.224)$. However, when analyzing the factor "Tray type" individually, implant I1 showed a lower gap value for $\mathrm{G} 1$ compared with $\mathrm{G} 2(\mathrm{p}=0.019)$.

Table 1 | Mean \pm Standard Deviation (SD) and Confidence of Interval 95\% (IC 95\%) of the mean gap for customized (G1) and self-perforating (G2) trays according to the different implant locations (I1, I2, I3).

\begin{tabular}{|c|c|c|c|c|c|c|c|}
\hline & \multicolumn{2}{|c|}{ I1 } & \multicolumn{2}{|c|}{12} & \multicolumn{2}{|c|}{13} & \multirow{2}{*}{$p$} \\
\hline & Mean \pm SD & IC 95\% & Mean $\pm S D$ & IC 95\% & Mean $\pm S D$ & IC95\% & \\
\hline G1 & $73.31 \pm 26.01$ * & $49.26 ; 97.37$ & $149.16 \pm 53.90$ & 99.30; 199.02 & $115.46 \pm 73.34$ & 41.63;183.30 & $>0.05$ \\
\hline G2 & $154.41 \pm 74.64$ & $85.37 ; 223.44$ & $159.45 \pm 87.64$ & $78.39 ; 240.51$ & $109.28 \pm 49.18$ & $61.28 ; 155.26$ & $>0.05$ \\
\hline$p$ & \multicolumn{2}{|c|}{$<0.05$} & \multicolumn{2}{|c|}{$<0.05$} & \multicolumn{2}{|c|}{$<0.05$} & \\
\hline
\end{tabular}

*Represents statistically significant difference $(p<0.05)$ 


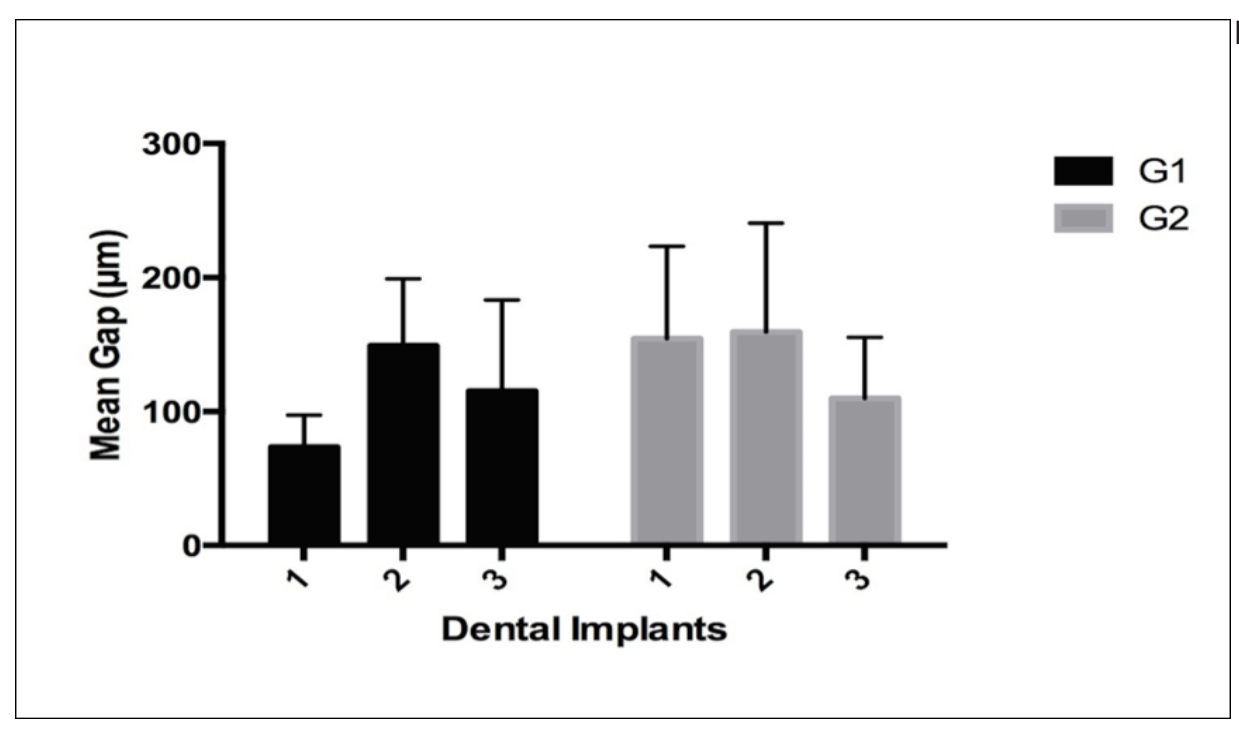

Figure 4 | Illustrative comparison of mean and $95 \%$ confidence interval for the mean gap between tray type (G1 and G2) for different dental implant locations (I1, 12 and I3).

\section{DISCUSSION}

Based on the data, the null hypothesis, that there would be no difference in impressions obtained through both methods, was rejected for this study. The self-perforating tray showed a smaller accuracy in implant impression when compared with conventional customized trays. These findings are consistent with previous studies. The same tray was previously evaluated by Marotti et al., who found less accuracy of the self-perforating tray when evaluating the gap obtained by impressions taken in the mandibular arch. ${ }^{15}$ In addition, Damodara et al. reported that custom trays are more accurate than stock trays. ${ }^{16}$

Only dental implant I1 showed a statistical difference in the mean gap value for self-perforating and custom trays. Although Gökçen-Rohlig et al. found different accuracies for posterior and anterior dental implants, in this study this difference was not attributed to the implant location, but to theimpression technique. ${ }^{17}$ According to Burns et al., the accuracy of impression depends on tray rigidity, which does not allow distortion of the impression. ${ }^{1}$ Possibly, this tray might be more flexible than custom trays' impression material, leading to the distortion if impression material during the tray removal.
It should be taken into consideration that the quality of impression will be determined by a number of factors, such as impression materials, techniques, and number of implants ${ }^{18,19}$. To minimize the interference of impression material in the results, all impressions were taken by the same professional, using a highly accurate material with minimal deformation, for both groups. ${ }^{16}$ Regarding impression technique, the splinted technique was not used to avoid the influence of impression technique on the results, since this aspect was not within the scope of the study. Nevertheless, it must be emphasized that the fit of a bar in an edentulous arch with four implants may easily be achieved with a splinted pick-up impression, ${ }^{20}$ and that the self-perforating tray may be used with a splinted pick-up impression.

Groten et al. suggested the measurements of fifty different sites to achieve a reliable result of mean gap. ${ }^{24}$ In the present study the entire gap area was evaluated to determine a mean gap, that is, the measurements sites were equally distributed according to the gap area. Thus, the number of measurement sites varied to each evaluated implant. 
In summary, the quality of implant impression is determinant to obtain an accurate cast ${ }^{21}$ and the success of treatment ${ }^{22}$. Although several technical factors must be considered to achieve this, an ideal impression requires minimal procedure time and must be useful and comfortable to the patient. ${ }^{23}$ Self-perforating trays comply with the requirements described above, however, their accuracy must be further investigated.

\section{CONCLUSION}

Within the limitations of this study, the selfperforating trays provided similar accuracy to that of conventional open trays for implant impression of the maxillary edentulous arch.

\section{REFERENCES}

1. Burns J, Palmer R, Howe L, Wilson R. Accuracy of open tray implant impressions: an in vitro comparison of stock versus custom trays. J Prosthet Dent. 2003 Mar;89(3):205-5. doi: $10.1067 / \mathrm{mpr} .2003 .38$.

2. Ehsani S, Siadat H, Alikhasi M. Comparative evaluation of impression accuracy of tilted and straight implants in allon-four technique. Implant Dent. 2014 Apr;23(2):225-30. doi: 10.1097/ID.0000000000000064.

3. Lee H, So JS, Hochstedler JL, Ercoli C. The accuracy of implant impressions: a systematic review. J Prosthet Dent. 2008 Oct;100(4):285-91. doi: 10.1016/Soo22-3913(08)60208-5.

4. Ozcelik TB, Yilmaz B. A functional open-tray impression technique for implant-retained overdenture prostheses. J Oral Implantol. 2012;38(5):617-9. doi: 10.1563/AAID-JOI-D-10-00159. Epub 2011 Jun 8.

5. Vigolo P, Majzoub Z, Cordioli G. Evaluation of the accuracy of three techniques used for multiple implant abutment impressions. J Prosthet Dent. 2003 Feb;89(2):186-92. doi: 10.1067/mpr.2003.15.

6. Deogade SC, Dube G. A sectional-splinting technique for impressing multiple implant units by eliminating the use of an open tray. Contemp Clin Dent. 2014 Apr-Jun;5(2):221-6. doi: 10.4103/0976-237X.132347.

7. Ender A, Mehl A. Accuracy of complete-arch dental impressions: a new method of measuring trueness and precision. J Prosthet Dent. 2013 Feb;109(2):121-8. doi: 10.1016/Soo22-3913(13)6oo28-1.
8. Papaspyridakos P, Benic GI, Hogsett VL, White GS, Lal K, Gallucci GO. Accuracy of implant casts generated with splinted and non-splinted impression techniques for edentulous patients: an optical scanning study. Clin Oral Implants Res. 2012 Jun;23(6):676-81. doi: 10.1111/j.1600-0501.2011.02219.x.

9. Al-Abdullah K, Zandparsa R, Finkelman M, Hirayama H. An in vitro comparison of the accuracy of implant impressions with coded healing abutments and different implant angulations. J Prosthet Dent. 2013 Aug;110(2):90-100. doi: 10.1016/Soo22-3913(13)60346-7.

10. Lewis MB, Klineberg I. Prosthodontic considerations designed to optimize outcomes for single-tooth implants: a review of the literature. Aust Dent J. 2011 Jun;56(2):181-92. doi: 10.1111/j.1834-7819.2011.01322.x.

11. Lin W-S, Harris BT, Morton D. The use of a scannable impression coping and digital impression technique to fabricate a customized anatomic abutment and zirconia restoration in the esthetic zone. J Prosthet Dent. 2013 Mar;109(3):187-91. doi: 10.1016/Soo22-3913(13)60041-4.

12. Kwon J-H, Son YH, Han CH, Kim S. Accuracy of implant impressions without impression copings: a three-dimensional analysis. J Prosthet Dent. 2011 Jun;105(6):367-73. doi: 10.1016/Soo22-3913(11)60075-9.

13. Raviv E, Hanna J, Raviv R, Harel-Raviv M. A clinical report on the use of closed-tray, hex-lock-friction-fit implant impression copings. J Oral Implantol. 2014 Aug;40(4):449-53. doi: 10.1563/AAID-JOI-D-11-00056.

14. Geramipanah F, Sahebi M, Davari M, Hajimahmoudi M, Rakhshan V. Effects of impression levels and trays on the accuracy of impressions taken from angulated implants. Clin Oral Implants Res. 2015 Sep;26(9);1098-105. doi: 10.1111/clr.12410.

15. Marotti J, Tortamano P, Castilho TR, Steagall W Jr, Wolfart S, Haselhuhn K. Accuracy of a self-perforating impression tray for dental implants. J Prosthet Dent. 2014 Oct;112(4):843-8. doi: 10.1016/j.prosdent.2014.02.012.

16. Damodara EK, Litaker MS, Rahemtulla F, McCracken MS. A randomized clinical trial to compare diagnostic casts made using plastic and metal trays. J Prosthet Dent. 2010 Dec;104(6):364-71. doi: 10.1016/Soo22-3913(10)60167-9.

17. Gökçen-Rohlig B, Ongül D, Sancakli E, Sermet B. Comparative evaluation of the effects of implant position, impression material, and tray type on implant impression accuracy. Implant Dent. 2014 Jun;23(3):283-8. doi: 10.1097/ID.oooooooooooooo59.

18. Linkevicius T, Svediene O, Vindasiute E, Puisys A, Linkeviciene L. The influence of implant placement depth and impression material on the stability of an open tray impression coping. J Prosthet Dent. 2012 Oct;108(4):238-43. doi: 10.1016/Soo22-3913(12)60169-3. 
19. Sorrentino R, Gherlone EF, Calesini G, Zarone F. Effect of implant angulation, connection length, and impression material on the dimensional accuracy of implant impressions: an in vitro comparative study. Clin Implant Dent Relat Res. 2010 May;12(Suppl 1):e63-76. doi: 10.1111/j.1708-8208.2009.00167.x.

20. Stimmelmayr M, Güth JF, Erdelt K, Happe A, Schlee M, Beuer F. Clinical study evaluating the discrepancy of two different impression techniques of four implants in an edentulous jaw. Clin Oral Investig. 2013 Nov;17(8):1929-35. doi: 10.1007/s00784-012-0885-z.

21. Jo SH, Kim KI, Seo JM, Song KY, Park JM, Ahn SG. Effect of impression coping and implant angulation on the accuracy of implant impressions: an in vitro study. J Adv Prosthodont. 2010 Dec;2(4):128-33. doi: 10.4047/jap.2010.2.4.128.
22. Balamurugan T, Manimaran P. Evaluation of accuracy of direct transfer snapon impression coping closed tray impression technique and direct transfer open tray impression technique: an in vitro study. J Indian Prosthodont Soc. 2013 Sep;13(3):226-32. doi: 10.1007/s13191-012-0141-x.

23. Avila ED, Matos Moraes F, Castanharo SM, Del'Acqua MA, Assis Mollo F. Effect of splinting in accuracy of two implant impression techniques. J Oral Implantol. 2014 Dec;40(6):633-9. doi: 10.1563/AAID-JOI-D-12-00198.

24. Groten M, Axmann D, Pröbster L, Weber H. Determination of the minimum number of marginal gap measurements required for practical in vitro testing. J Prosthet Dent. 2000 Jan;83(1):40-9.

25. Zaghloul HH, Younis JF. Marginal fit of implant-supported all-ceramic zirconia frameworks. J Oral Implantol. 2013 Aug;39(4):417-24. doi: 10.1563/AAID-JOI-D-11-00103. 